\title{
An extraordinary mechanism causing intraoperative migration of the Kirschner-wire
}

\author{
Ameliyat sırasında Kirschner-telinin yer değiştirmesine neden olan sıra dışı bir mekanizma
}

\author{
Mehmet Eroğlu, MD., Özal Özcan, MD., İhsan Şentürk, MD., Mehmet Yücehan, MD. \\ 'Department of Orthopedics and Traumatology, Medical Faculty of Afyon Kocatepe University, Afyonkarahisar, Turkey
}

\begin{abstract}
Migration of Kirschner wires (K-wires) postoperatively and with use of cannulated implants intraoperatively is a well-known complication. In this article, we present an extraordinary mechanism causing intraoperative migration of a K-wire. A K-wire which was used for temporary fixation of fracture fragments migrated forwardly due to its contact with the drill bit while drilling a hole for a screw. The interaction between the K-wire and the drill bit simulated a gear wheel effect and thus the rotating K-wire advanced. Although no complications occurred in this case, we believe that the mentioned mechanism may be of importance particularly in osteoporotic patients and may cause damage to vital structures.
\end{abstract}

Keywords: Complication; fracture; Kirschner wire; migration.
$\ddot{O} Z$

Kirschner tellerinin (K-teli) ameliyat sonrasında ve kanüllü implantların kullanımı ile ameliyat sırasında yer değiştirmesi bilinen bir komplikasyondur. Bu yazıda ameliyat sırasında K-telinin yer değiştirmesine neden olan sıra dışı bir mekanizma sunuldu. Kırık fragmanlarının geçici tespiti için kullanılan bir K-teli, bir vida deliği açılırken dönen matkap ucunun teması sonucunda ileriye doğru yer değiştirdi. K-teli ve matkap ucu arasındaki etkileşim bir dişli çark etkisi oluşturdu ve böylece dönen K-teli ilerledi. Her ne kadar bu olguda herhangi bir komplikasyon oluşmamış olsa da bahsedilen mekanizmanın özellikle osteoporotik hastalarda önemli olabileceği ve hayati yapılarda yaralanmaya neden olabileceği düşünüldü.

Anahtar sözcükler: Komplikasyon; kırık; Kirschner teli; yer değiştirme.

\section{CASE REPORT}

A 53-year-old male patient was admitted to our hospital complaining of pain in the right hip after a fall from height. An intertrochanteric fracture with a butterfly fragment was detected. After separation of the fragment, the fracture line was transverse and fixation of the fracture by closed means would be very difficult as there was no support on the lateral side of the fracture. To evaluate the bony structures, a three-dimensional computed tomography scan was obtained. The proximal fragment of the fracture was not large enough to allow entrance for a proximal femoral nail, and, while introducing the devices, the femoral neck would fracture and result in the need for prosthetic replacement. Therefore, an open reduction and plate

\footnotetext{
- Received: February 04, 2015 Accepted: July 02, 2015
}

- Correspondence: Mehmet Eroğlu, MD. Afyon Kocatepe Üniversitesi Tıp Fakültesi Ortopedi ve Travmatoloji Anabilim Dalı, 03200 Afyonkarahisar, Turkey. Tel: +90 535 - 6652031 Fax: +90 272 - 2463300 e-mail: meroglufb@gmail.com 

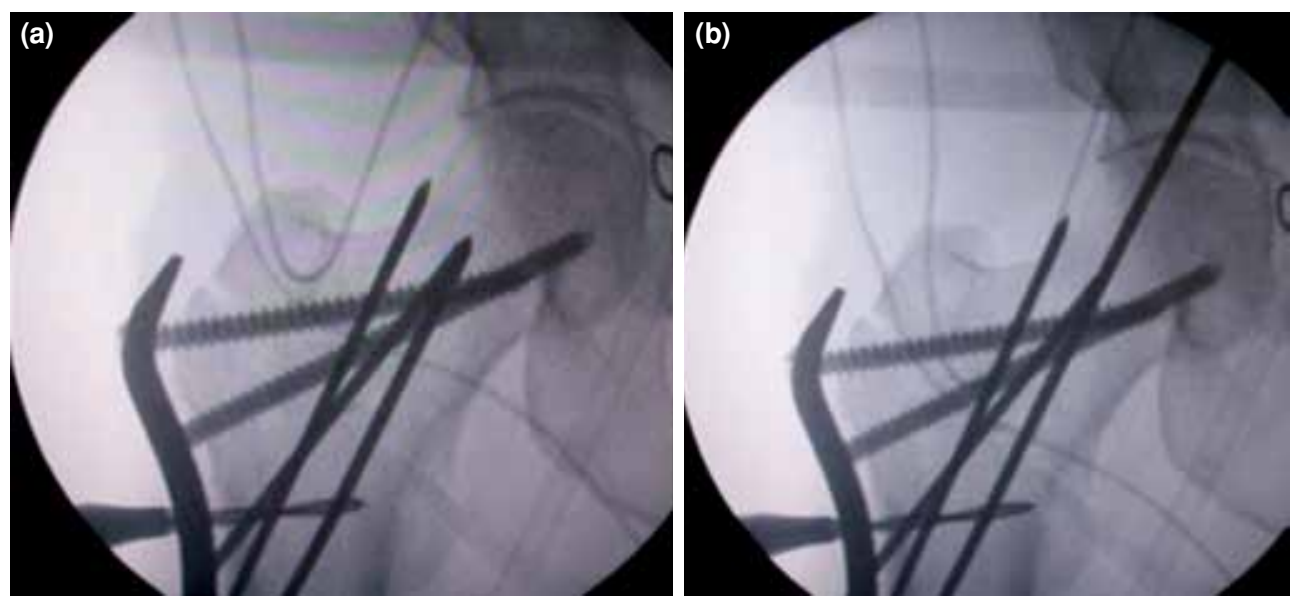

Figure 1. (a) Hole for third proximal screw is drilled, (b) Right after, a resistance is felt and temporary $\mathrm{K}$-wire is seen to migrate.

fixation was planned. A written informed consent was obtained from the patient.

During the surgery, the fracture fragments were temporarily fixated by using K-wires. Afterwards, two screws engaging the femoral neck were placed on the plate. While drilling the hole for the third proximal screw, a slight resistance was felt which was not thought to be of importance and the drilling continued. On the fluoroscopic view, the K-wire was observed to advance (Figure 1a, b).

Fortunately, the K-wire was directed distal to proximally, lateral to medially and anterior to posteriorly and did not penetrate any vital structures or the joint surface of the femoral head. The K-wire was pulled back and the plate fixation was completed. While seeking the mechanism for migration, tracks made by the drill on the migrated K-wire were detected (Figure 2a, b). Interestingly, the interaction between the drill bit and the K-wire had acted as a gear wheel, and resulted in both rotation and advancement of the K-wire (Figure 3).
In the postoperative period, the patient had no neurovascular problems and the fracture healed uneventfully with full range of motion of the hip. The patient had no complaints after 18 months of follow-up.

\section{DISCUSSION}

Mazet was the first to report intrathoracic migration of a K-wire in 1943. ${ }^{[4]}$ Later, many authors have reported complications caused by K-wires migrating especially from the shoulder girdle to different anatomic compartments such as thorax, abdomen and more rarely to the neck, the spine or the pelvis. The intrathoracic sites for wire migration included the pleural space, pulmonary parenchyma, mediastinum, cardiaccavities, pericardial space, aorta, and pulmonary artery. The reported intraabdominal sites for wire migration were the spleen, liver, retroperitoneum, and aortic lumen. ${ }^{[1,2,6-9]}$ Even embolization of a K-wire has been reported. ${ }^{[10]}$ However, all those migrations had occurred after a certain period of time from the
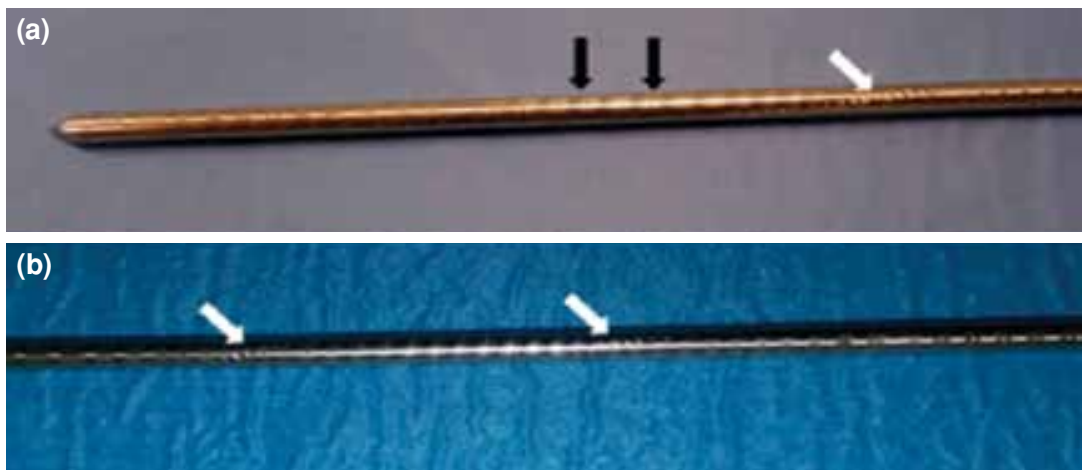

Figure 2. (a) Dark and light lines are visible, suggesting a rotational advancement (black arrows), (b) sharp tracks due to impact of edges of drill bit (white arrows). 


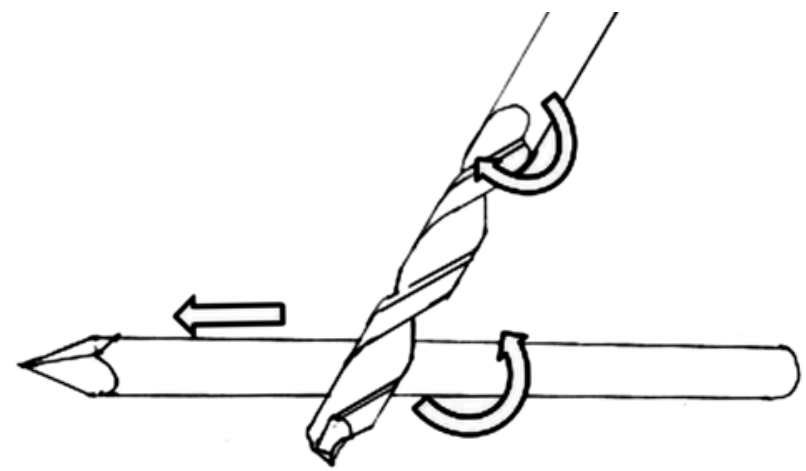

Figure 3. An illustration of mechanism for migration of Kirschner-wire (so called, gear wheel effect).

surgery, so the surgeons must be alert to for close follow-up.

Moreover, there are some reports that stated intraoperative migration of K-wires used with cannulated devices. ${ }^{[4,5]}$ Immediate migration of the K-wires does not seem possible without using cannulated devices; however, this happened in our case in an unexpected way. When the drill bit contacted the K-wire, the interaction between the drill bit and the K-wire acted as a gear wheel, and the K-wire advanced while rotating. To our knowledge, this is the only case to report such an extraordinary mechanism for immediate migration of a K-wire.

Although all kinds of wires (smooth, threaded, and bent) have been reported to migrate, the exact cause of migration is unclear. $^{[1]}$ There are some measures to prevent the K-wires from migration in the postoperative period. These include the use of threaded wires, bending the subcutaneous ends of the wires, close radiological follow-up, and withdrawing the wires at the end of treatment. ${ }^{[1]}$ The case presented is unique to occur intraoperatively without the use of cannulated devices and none of those measures could possibly prevent migration. Fortunately, in our case, migration of the K-wire did not result in any neurovascular injuries.

When using cannulated devices, it is highly recommended to visualise the tools and the implants on fluoroscopy at all stages of the surgery. ${ }^{[4]}$ We believe that one should control the position of a K-wire on fluoroscopy when even a slight resistance is encountered.

In conclusion, our experience suggests that, while using a temporary K-wire, it is important to adjust the orientation of the wire properly in order to protect the vital structures in case the wire advances.
During drilling procedures, the tip of drill bit should be directed away from the K-wires placed for temporary fixation of fracture fragments. The surgeon should keep in mind that the interaction between the drill bit and the K-wire may act as a gear wheel, and the K-wire may advance with rotation. Additionally, when a resistance is felt (even if a slight one), drilling must be stopped and the position of temporary K-wire and the drill bit must be checked on fluoroscopy. Although the abovementioned patient was not osteoporotic, we believe that the mechanism for migration of the wire might be more important especially in osteoporotic patients. ${ }^{[1]}$

\section{Declaration of conflicting interests}

The authors declared no conflicts of interest with respect to the authorship and/or publication of this article.

\section{Funding}

The authors received no financial support for the research and/or authorship of this article.

\section{REFERENCES}

1. Mellado JM, Calmet J, García Forcada IL, Saurí A, Giné J. Early intrathoracic migration of Kirschner wires used for percutaneous osteosynthesis of a two-part humeral neck fracture: a case report. Emerg Radiol 2004;11:49-52.

2. Kędra M, Rybojad $P$, Jendrej J, Sawicki M. Intraspinal K-wire migration after humeral fracture fixation. Eur J Cardiothorac Surg 2011;39:1079.

3. Wu YH, Lai CH, Luo CY, Tseng YL. Tracheoinnominate artery fistula caused by migration of a Kirschner wire. Eur J Cardiothorac Surg 2009;36:214-6.

4. Sayegh FE, Tsintzas D, Kapetanos GA. Intrapelvic migration of a guide pin during fixation of a hip fracture: who and what is to blame? Acta Orthop Belg 2005;71:239-41.

5. Kumar S, Singh SK, Jayant K, Agrawal S, Parmar KM, Ajjoor Shankargowda S. Forgotten Kirschner wire causing severe hematuria. Case Rep Urol 2014;2014:305868.

6. Marya KM, Yadav V, Rattan KN, Kundu ZS, Sangwan SS. Unusual K-wire migration. Indian J Pediatr 2006;73:1107-8.

7. Yurtçu M, Senaran H, Türk HH, Abasıyanık A, Tuncay I. Migration of intra-articular K-wire into the contralateral pelvis after surgery for developmental dysplasia of the hip: a case report. Acta Orthop Traumatol Turc 2010;44:413-5.

8. Karaman I, Kafadar IH, Oner M, Halici M. Intrapelvic pin migration after Salter innominate osteotomy and laparoscopic removal: a case report. J Pediatr Orthop B 2013;22:533-5.

9. Julià D, Baldó X, Gómez N, Mármol E. Transthoracic migration of a Kirschner wire from the humerus to the abdomen. Eur J Cardiothorac Surg 2012;41:1197-8.

10. Seipel RC, Schmeling GJ, Daley RA. Migration of a K-wire from the distal radius to the heart. Am J Orthop (Belle Mead NJ) 2001;30:147-51.

11. Onuma K, Shintani R, Fujimaki H, Sukegawa K, Kenmoku $\mathrm{T}$, Uchida $\mathrm{K}$, et al. Total wrist arthrodesis with wrist fusion rod in patients with rheumatoid arthritis. Eklem Hastalik Cerrahisi 2015;26:41-8. 